ks. Henryk Sławiński

\title{
Wychowanie w rodzinie do słuchania słowa Bożego
}

Zadaniem poniższych rozważań jest zwięzłe i w miarę całościowe omówienie wychowania w rodzinie do słuchania słowa Bożego ${ }^{1}$. Jest to zagadnienie należące do obszaru pedagogiki i homiletyki. Jego aktualność wzmacnia fakt, że w 2008 roku od 5 do 26 października odbyło się w Rzymie XII Zwyczajne Zgromadzenie Ogólne Synodu Biskupów, którego tematem było Słowo Boże w życiu i misji Kościoła. Niniejsze rozważania harmonizują z troską biskupów o to, by w Kościele ponownie odkryto żywe i skuteczne słowo Boże. Ostatni papieże: Jan Paweł II i Benedykt XVI wielokrotnie zachęcali wiernych do spotkania ze słowem Bożym w przekonaniu, że właśnie ono przyniesie Kościołowi nową wiosnę duchową ${ }^{2}$ Podejmując wspomniany temat, najpierw zastanowimy się nad możliwością wychowania do słuchania słowa Bożego, następnie zwrócimy uwagę na rolę rodziców w tym procesie, a potem kolejno przedstawimy cel, metody, zasady i owoce omawianego wychowania.

\section{Możliwość wychowania do słuchania słowa Bożego}

Według mądrego przysłowia zostaliśmy wyposażeni w dwoje uszu i tylko w jedne usta, abyśmy przynajmniej dwa razy więcej słuchali, niż mówili. Badania prenatalne wykazały, że dziecko już w łonie matki słyszy dźwięki. Mówić uczy się dopiero po wielu miesiącach przebywania wśród ludzi. Dziecko poczęte słyszy, ale czy słucha? Trudno polemizować ze stwierdzeniem, że człowiek uczy się słuchać znacznie później niż mówić. Potrzebuje czasu, by zrozumieć, że mowa jest srebrem, a milczenie złotem.

${ }^{1} \mathrm{O}$ pewnych aspektach omawianego tu zagadnienia traktują artykuły: M. Śnieżyński, Jak wychowywać ludzi do stuchania, [w:] Stuchacz słowa, red. W. Przyczyna, Kraków 1998, s. 289-197; E. Staniek, Wychowanie do stuchania słowa Bożego, [w:] Stuchacz słowa, dz. cyt., s. $298-310$.

${ }^{2}$ Por. Benedykt XVI, Do uczestników kongresu z okazji 40 rocznicy ogłoszenia soborowej Konstytucji ,Dei Verbum” (16 IX 2005), „L'Osservatore Romano” wyd. polskie 11-12 (2005), s. 24-25; Jan Paweł II, Audiencja generalna (22 V 1985), „L'Osservatore Romano” wyd. polskie 4-5 (1985), s. 21. 
Czy trzeba uczyć się słuchania, tak jak uczymy się mówienia? Owszem! Ileż to razy zdarza się, że ktoś słucha, a nie słyszy. Skoro słuchanie innych ludzi nastręcza trudności, o ileż trudniej słuchać słowa Bożego. Czy zatem można wychować człowieka do słuchania słowa Bożego? Na taką możliwość wskazuje znany epizod z życia Anny i Elkany, którzy oddali swego syna Samuela na wychowanie kapłanowi Helemu. Pewnego dnia „Pan zawołał Samuela, a ten odpowiedział: «Oto jestem». Potem pobiegł do Helego, mówiąc mu: «Oto jestem: przecież mię wołałeś». Heli odrzekł: «Nie wołałem cię, wróć i połóż się spać». Położył się zatem spać. [...] I znów Pan powtórzył po raz trzeci swe wołanie: «Samuelu!» Wstał więc i poszedł do Helego, mówiąc: «Oto jestem: przecież mię wołałeś». Heli spostrzegł się, że to Pan woła chłopca. Rzekł więc Heli do Samuela: «Idź spać! Gdyby jednak kto cię wołał, odpowiedz: Mów, Panie, bo sługa Twój słucha». Odszedł Samuel, położył się spać na swoim miejscu. Przybył Pan i stanąwszy, zawołał jak poprzednim razem: «Samuelu, Samuelu!» Samuel odpowiedział: «Mów, bo sługa Twój słucha»" (1 Sm 3, 4-5. 8-10).

Heli nauczył Samuela, aby słuchał Boga. Czy Pan Bóg potrzebował pośrednictwa kapłana, i to nie całkiem przykładnego? Będąc wszechmocnym, mógłby przecież przedstawić się Samuelowi bez zachęty Helego. Bóg jednak wybiera inną, pośrednią drogę: włącza ludzi do współdziałania ze sobą i powierza ludziom wychowanie do słuchania swego słowa.

\section{Rodzice podstawowym podmiotem \\ wychowania do słuchania słowa Bożego}

Obecnie rozumie się wychowanie najczęściej jako pomoc w samowychowaniu, czyli w samodzielnej aktywności człowieka zmierzającej do jego wszechstronnego rozwoju fizycznego, intelektualnego i moralnego. Każdy człowiek jako osoba ma niezbywalne, bierne prawo do wychowania niezależnie od wieku. Wszystkim ludziom przysługuje prawo do wychowania naturalnego. Jego uzupełnieniem i udoskonaleniem jest wychowanie nadnaturalne, chrześcijańskie, które przysługuje wszystkim ochrzczonym ${ }^{3}$.

Prawu człowieka do wychowania odpowiada obowiązek wychowawczy spoczywający w pierwszym rzędzie na rodzicach, których opiece Bóg powierzył dar życia. Rodzice są na ziemi pierwszorzędnym podmiotem wychowania wspieranym przez instytucje państwowe i kościelne. Na rodzicach katolickich spoczywa dodatkowo obowiązek wychowania dzieci w wierze swego Kościoła. Już podczas zawierania małżeństwa decydują się po

${ }^{3}$ Por. S. Dziekoński, Rozwój wychowawczej myśli Kościoła na przestrzeni ostatnich wieków, Warszawa 2004, s. 50. 
katolicku wychować potomstwo, jakim zostaną obdarzeni przez Boga. Ponawiają tę decyzję podczas chrztu swych dzieci. Istotnym elementem tego wychowania jest udostępnienie słowa Bożego.

Od rodziców dziecko słyszy pierwsze słowa, a później, z biegiem lat wyjaśnienia dotyczące życia, świata, Boga. Jedynie w 16 proc. młody człowiek przejmuje prawdy wiary i zasady moralne od Kościoła instytucjonalnego, a w 57 proc. - od rodziców. Wpływ rodziców jest w tym zakresie trzykrotnie większy niż Kościoła ${ }^{4}$. Rodzice nie mogą nie wychowywać. Robią to jedynie dobrze bądź źle. Zdarza się, że niektórzy rodzice nie proszą o chrzest dziecka, wychodząc z założenia, iż to same dzieci, gdy dorosną, wybiorą dla siebie wiarę. Ci sami rodzice jednak nie zatykają dzieciom uszu, czekając, żeby dzieci same, gdy dorosną, wybrały język, jakim chciałyby się posługiwać. Jeśli więc nawet rodzice nie podejmują świadomie czynności wychowawczych, również wtedy dokonuje się w rodzinie socjalizacja, czyli uspołecznienie, kształtowanie osobowości dziecka przez przekazywanie mu wartości, norm postępowania, praw i obowiązków akceptowanych i uznawanych za właściwe. Natomiast świadomie podejmowane czynności wychowawcze mają określony cel.

\section{Cel wychowania do słuchania słowa Bożego}

Ogólnym celem wychowania do słuchania słowa Bożego jest integralna wiara wychowanka niezbędna do zbawienia. Osiąga się go przez realizację szeregu celów szczegółowych, jakimi są:

- budzenie wrażliwości na istnienie Boga, który żyje, mówi i działa,

- utrwalenie w wychowanku przekonania, że słuchanie słowa Bożego jest niezbędną praktyką w życiu chrześcijanina,

- rozbudzenie głodu słowa Bożego i kształcenie nawyku słuchania słowa Bożego,

- uwrażliwienie na słowo Boże kierowane do człowieka przez świat stworzony, przez głos sumienia, podczas celebracji liturgicznych i katechezy,

- zapoznanie z historią zbawienia,

- kształtowanie umiejętności interpretowania świata przez pryzmat słowa Bożego,

- kształtowanie postawy posłuszeństwa słowu Bożemu na wzór bohaterów znanych z Biblii i historii Kościoła,

${ }^{4}$ Por. W. Przyczyna, Rola przepowiadania słowa Bożego w kształtowaniu uczniów Chrystusa dziś, [w:] Komisja Duszpasterstwa Konferencji Episkopatu Polski, Kościót niosacy Ewangelię nadziei. Program duszpasterski Kościoła w Polsce na lata 2006-2010. Rok 2007/2008-Badźmy uczniami Chrystusa, Poznań 2007, s. 184 [179-190]. 
- dostarczenie mocy do przeciwstawiania się pokusom na wzór Chrystusa, który na pustyni odpierał ataki szatana słowem Bożym,

- kształtowanie umiejętności posługiwania się językiem religijnym,

- wychowanie do ofiarowania siebie i swego czasu Bogu, co jest istotne w kulcie religijnym.

\section{Metody wychowania do słuchania słowa Bożego}

Osiągnięciu wymienionych celów służą różne metody wychowawcze, czyli zamierzony i celowy sposób oddziaływania wychowawczego, najczęściej na dzieci i młodzież, w celu ukształtowania u podopiecznych postaw i nawyków pożądanych z moralnego i wychowawczego punktu widzenia 5 . Tu dotykamy sedna podjętego zagadnienia: jaką metodę należy zastosować, by umożliwić rozwój duchowego zmysłu słuchaczy, który jest niezbędny do odbioru słowa Bożego? Metody wychowawcze powinny być dostosowane do wieku i predyspozycji wychowanka. Jedne można stosować we wczesnym wieku rozwoju dziecka, inne - gdy dziecko podrośnie. Niezależnie od wieku dziecka, zawsze można i należy stosować metodę osobistego przykładu.

\section{OSOBISTY WPŁYW}

Przykład rodziców jest pierwszą i najważniejszą metodą wychowawczą. W pierwotnym Kościele sprawę religijnego wychowania dzieci powierzono rodzicom. Zgodnie z tradycją żydowską, do której nawiązywało chrześcijaństwo, przede wszystkim na ojcu spoczywał obowiązek przygotowania dzieci do wyznania wiary: „Słuchaj, Izraelu, Pan jest naszym Bogiem - Panem jedynym" (Pwt 6, 4-7).

Wzmianki o rodzicach wielu sławnych biskupów i pisarzy chrześcijańskich epoki patrystycznej świadczą o tym, że umiejętnie wychowali oni swoje dzieci. A i w naszych czasach nie brakuje dobrych przykładów. W książce pt. Krag biblijny Roman Brandstaetter (1906-1987) zamieścił następujące wyznanie: „Biblia leżała na biurku mojego dziadka. Biblia leżała na stołach moich praojców. Nigdy w bibliotece. W naszym domu nikt Biblii nigdy nie szukał. [...] Gdy ojciec wieczorem czytał Biblię, chodziłem po pokoju na palcach. Dziadkowi nigdy bym się nie ośmielił przerwać tej lektury. Obaj byli dla mnie w takich chwilach naznaczeni przywilejem nietykalności. [...] Ojciec opowiadał mi, że pradziadek, ilekroć sięgał po Biblię, mył uprzednio ręce i modlił się o łaskę mądrego czytania”. Dzieci, patrząc na

${ }^{5}$ Por. J. Mastalski, Zarys teorii wychowania, Kraków 2002, s. 163-168; Pedagogika i psychologia. Zagadnienia, pojęcia, terminy, oprac. K. Janus, Warszawa 2006, s. 94.

${ }^{6}$ R. Brandstaetter, Krag biblijny, Warszawa 1977, s. 16-17. 
rodziców pochylonych nad księgą Pisma Świętego bądź brewiarzem, uczą się respektowania ciszy i fascynacji słowem Bożym.

\section{OPOWIADANIE}

Inną metodą, która wprowadza w świat słowa Bożego, jest jego opowiadanie. Wszyscy rodzice wiedzą, jak bardzo ich dzieci lubią słuchać różnych opowieści, szczególnie gdy są przekazywane w nieco udramatyzowany sposób. Biblia aż roi się od pięknych opowiadań, które rodzice moga przekazać dzieciom. A gdy dzieci nauczą się czytać, zachęcone przez rodziców, same mogą sięgać po Pismo Święte w wydaniu dostosowanym do swego wieku.

Wspomniany już Roman Brandstaetter tak był zasłuchany w biblijne opowiadania swego dziadka, iż początkowo był przekonany, że to on napisał Biblię. Zapamiętał też otrzymany od dziadka testament: „Będziesz Biblię nieustannie czytał. [...] Będziesz ją kochał więcej niż rodziców... Więcej niż mnie... Nigdy się z nią nie rozstaniesz... A gdy zestarzejesz się, dojdziesz do przekonania, że wszystkie książki, jakie przeczytałeś w życiu, są tylko nieudolnym komentarzem do tej jedynej Księgi..."7.

\section{BIBLIJNA INTERPRETACJA ŻYCIA}

Kolejną metodą wychowawczą jest biblijna interpretacja życia. Wierzymy, że Bóg nie tylko stworzył świat, ale też nadal podtrzymuje go w istnieniu i kieruje biegiem historii. Dlatego też od czasów Abrahama historia ludzi postrzegana jest jako dzieje zbawienia. Na przestrzeni wieków prorocy interpretowali wydarzenia z życia narodu wybranego przez pryzmat wiary. Widziane z tej perspektywy dzieje ludzkie zostały utrwalone w księdze Pisma Świętego. Do istoty wiary należy interpretowanie świata i tego, co się w nim dzieje, przez pryzmat słowa Bożego. W Orędziu na XXI Światowy Dzień Młodzieży papież Benedykt XVI zachęcał młodych do tego, by dobrze poznawali Biblię, trzymali ją w zasięgu ręki, aby była dla nich niczym kompas wskazujący drogę, którą należy iść ${ }^{8}$. Wzorem jest tu psalmista, który wyznaje o Bogu: „Twoje słowo jest lampą dla moich stóp i światłem na mojej ścieżce” (Ps 119, 105). Dla człowieka wierzącego nic nie jest przypadkiem. Wierzący rodzice interpretują codzienne wydarzenia jako znaki, przez które mówi do nich Bóg, i w takie postrzeganie świata wprowadzają swoje dzieci. Biblijna interpretacja życia stanowi bardzo dojrzałą metodę wychowania do słuchania słowa Bożego. Potrze-

\footnotetext{
${ }^{7}$ R. Brandstaetter, Krag biblijny, dz. cyt., s. 10.

${ }^{8}$ Por. Orędzie na XXI Światowy Dzień Młodzieży (9 IV 2006), „LOSservatore Romano” wyd. polskie 4 (2006), s. 6-8.
} 
ba bowiem zżycia z Bogiem, aby w różnych sytuacjach życiowych spontanicznie odwoływać się właśnie do Jego słowa. Jest to szczególnie pomocne w obliczu sytuacji granicznych, wpływających na bieg życia rodziny. Są wśród nich wydarzenia radosne, jak narodzenie kolejnego dziecka, przeprowadzka do nowego mieszkania, ale też smutne, jak nieszczęśliwy wypadek, nieuleczalna choroba, śmierć.

\section{WYPRAWA OTWARTYCH OCZU}

Słowo Boże zostało przekazane ludziom w różnorodnej formie. Pierwotną, skierowaną do wszystkich ludzi formą słowa Bożego jest otaczający nas wszechświat. Dzieło stworzenia mówi o swym Stwórcy w sposób przystępny dla każdego człowieka: „Albowiem od stworzenia świata niewidzialne Jego przymioty - wiekuista Jego potęga oraz bóstwo - stają się widzialne dla umysłu przez Jego dzieła” $(\mathrm{Rz} 1,20)$. Wiele nawiązań do przyrody: do ptaków, lisów, lilii, drzew można spotkać w ewangelicznych wypowiedziach Chrystusa. Świat jest tak piękny i tajemniczy, iż nie przestaje przemawiać do ludzi. Zdaniem św. Efrema „Mojżesz w swej księdze opisuje stworzenie całej natury, aby natura i księga dały świadectwo Stwórcy; natura poprzez korzystanie z niej, księga poprzez lekturę. Są to świadkowie, którzy wszędzie docierają. Są obecni we wszystkich czasach, w każdej godzinie" .

Szczególny zachwyt pięknem świata i gotowość poznawania jego praw i tajemnic przejawiają dzieci i młodzież. Pielęgnując zachwyt nad pięknem świata, rodzice wychowują swoje dzieci do odbioru wizualnego słowa Bożego, jakim jest wszechświat. Pomocą służą tu niektóre pieśni, arcydzieła polskiej literatury, z którymi dzieci i młodzież zapoznają się w szkole, jak np. Kiedy ranne wstaja zorze i Czego chcesz od nas, Panie, za Twe hojne dary ${ }^{10}$.

\section{PRAKTYKA MODLITWY RODZINNEJ}

Niezbędnym wymiarem wychowania do odbioru słowa Bożego w rodzinie jest modlitwa, czyli dialog z Bogiem. Jan Paweł II podkreślał, że „rodzice chrześcijańscy mają szczególne zadanie wychowania dzieci do modlitwy, wprowadzenia ich w stopniowe odkrywanie Bożego misterium i nauczenia osobistej z Nim rozmowy"11. Początkowo rodzice modlą się z dzieckiem tzw. pacierzem, czyli recytują z pamięci uświęcone tradycją, piękne teksty modlitw. Dzieci najpierw tylko obserwują rodziców, a potem uczą się podstawowych modlitw, jak Ojcze nasz, Zdrowaś Maryjo, Aniele Boży. Pa-

${ }^{9}$ Ephrem de Nisibe, Hymnes sur le paradis, V, 1-2, traduction du syriaque par R. Lavenant, introduction et notes par F. Graffin, Paris 1968, 71-72 (Sources Chrétiennes, 137).

${ }^{10}$ Por. E. Staniek, Wychowanie do stuchania słowa Bożego, art. cyt., s. 301, 308.

${ }^{11}$ Jan Paweł II, adhort. Familiaris consortio, 60. 
cierz to jednak tylko część modlitwy, bo jest on mówieniem do Boga. Na modlitwę składa się ponadto słuchanie Boga. Co więcej, owo zasłuchanie w słowo Boże i urzeczywistnianie rozpoznanej woli Bożej jest fundamentem dojrzewania w wierze. Taka właśnie wiara integralna, czyli wywierająca faktyczny wpływ na życie, jest - jak wspomnieliśmy - głównym celem wychowania do słuchania słowa Bożego.

Modlitwa, w której dowartościowane jest słuchanie Boga, pomaga w odkryciu, że to właśnie Bóg jest inicjatorem dialogu z człowiekiem, dialogu, którego zwieńczeniem jest komunia. Bóg bowiem, wypowiadając siebie, daje się nam nie tylko poznać, ale daje nam samego siebie, zapraszając do komunii z sobą (por. Sobór Watykański II, konst. Dei verbum, 2).

\section{RACHUNEK SUMIENIA}

Przeżywaniu osobistego kontaktu z Bogiem służy rachunek sumienia. Stanowi on również metodę, która rozwija umiejętność słuchania słowa Bożego. W jego świetle bowiem człowiek dostrzega, co udało mu się osiągnąć na drodze wiary i praktyki życia chrześcijańskiego, a co wymaga dalszej pracy nad sobą i zdecydowanych korekt. Kształtowanie sumienia dzieci i młodzieży wymaga od rodziców ogromnej delikatności. Bóg nie może być ukazywany jako groźny sędzia, ale jako ojciec, który jest zarazem sprawiedliwy i miłosierny. Jego słowo zaś służy nie tylko osądzeniu nas, ale jest też źródłem mocy do walki z pokusami, tak jak było nim dla Chrystusa kuszonego przez szatana na pustyni. Św. Paweł napisał, że to, „co niegdyś zostało napisane, napisane zostało i dla naszego pouczenia, abyśmy dzięki cierpliwości i pociesze, jaką niosą Pisma, podtrzymywali nadzieję" (Rz 15, 4). Słowo Boże ożywia nadzieję i chroni człowieka przed popadaniem w depresję w obliczu własnych słabości.

\section{SPOTKANIA Z MĄDRYMI LUDŹMI}

Autor Mądrości Syracha zachęca: „Chętnie słuchaj wszelkiego wykładu rzeczy Bożych, a przysłowia rozumne niech nie ujdą twojej uwagi! Jeżeli ujrzysz kogoś mądrego, już od wczesnego rana idź do niego, a stopa twoja niech ściera progi drzwi jego!” (Syr 6, 35-36). Jeśli rodzice przyjaźnią się z ludźmi mądrymi o dużym autorytecie osobistym i prowadzą z nimi wartościowe rozmowy, korzystają z nich również dzieci i młodzież. W słowach mądrych ludzi dochodzi do głosu mądrość Boża. Pewnym substytutem osobistych spotkań z mądrymi ludźmi jest lektura wartościowej literatury, szczególnie życiorysów świętych. Uczą oni słuchania i wypełniania słowa Bożego.

Pomocą w wychowaniu dzieci do słuchania słowa Bożego jest pozytywny stosunek rodziców do mediów katolickich: słuchanie muzyki chrześci- 
jańskiej i programów religijnych. Dorośli słuchając, uczą słuchać. Nie wyśmiewają tych mediów, ale wspierają je i korzystają z nich po to, by umocnić swą wiarę i poszerzyć wiedzę religijną, a także wytworzyć religijny klimat rodzinnych rozmów.

Po omówieniu celów i metod możemy przedstawić zasady wychowania do słuchania słowa Bożego.

\section{Zasady wychowania do słuchania słowa Bożego}

Przez zasady wychowania rozumie się ogół norm regulujących przebieg procesu wychowania, odnoszących się do celów i metod wychowawczych. W wychowaniu do słuchania słowa Bożego należy uwzględnić następujące zasady: relacyjności, systematyczności, harmonizacji z rokiem liturgicznym, interpretowania słowa Bożego zgodnie z nauką Kościoła i wprowadzania słowa w czyn.

\section{ZASADA RELACYJNOŚCI}

Podzielamy przekonanie wyrażone przez autora Listu do Hebrajczyków, że ,wielokrotnie i na różne sposoby przemawiał niegdyś Bóg do ojców przez proroków” (Hbr 1,1), ale najwyraźniej ,,przemówił do nas przez Syna" (Hbr 1,2). Dlatego też chrześcijaństwo nie jest religią księgi, ale słowa Bożego wcielonego w Chrystusie Jezusie. Zatem słuchanie słowa Bożego nie jest tylko przyjmowaniem czegoś do wiadomości, lecz wchodzeniem w relację z Bogiem, który w swej miłości przemawia do ludzi jak do przyjaciół i przestaje z nimi, aby zaprosić i przyjąć ich do wspólnoty z sobą (por. Sobór Watykański II, konst. Dei verbum, 2). Odpowiedzią człowieka na słowo Boże jest modlitwa. Św. Augustyn stwierdził: „Twoja modlitwa jest twym słowem skierowanym do Boga. Kiedy czytasz Biblię, Bóg mówi do ciebie; kiedy się modlisz, ty mówisz do Boga"12.

\section{ZASADA SYSTEMATYCZNOŚCI}

Nie da się najeść raz na zawsze. Nie da się wychowywać poprzez zorganizowanie pokazowego show. Skuteczne jest jedynie systematyczne i permanentne oddziaływanie. Również w życiu duchowym słowo Boże musi być traktowane jako stały i niezbędny pokarm. Znamienna jest pod tym względem wypowiedź św. Hieronima: „Ciało Pańskie jest prawdziwym pokarmem, a Jego Krew prawdziwym napojem; prawdziwym dobrem danym nam w obecnym życiu jest spożywać Jego Ciało i pić Jego Krew nie tylko

${ }^{12}$ Sancti Aurelii Augustini Enarrationes in Psalmos 85, 7, curaverunt D. E. Dekkers [...] et I. Fraipont, Turnholti 1956, 1177 (Corpus Christianorum. Series Latina, 39; Aurelii Augustini Opera. Pars 10, 2). 
podczas Eucharystii, ale również podczas lektury Pisma Świętego. Prawdziwym pokarmem i prawdziwym napojem jest bowiem Słowo Boże, z którego czerpiemy dzięki znajomości Pisma"13. Pokarm ten spełni swoje zadanie, gdy będzie spożywany regularnie.

\section{ZASADA HARMONIZACJI Z ROKIEM LITURGICZNYM}

Czas chrześcijanina wyznaczany jest nie tylko kalendarzem świeckim, ale także - liturgicznym. Zatem wychowanie do słuchania słowa Bożego powinno być dostosowane do rytmu życia Kościoła. Jemu to podporządkowane są artykuły w prasie katolickiej i homilie niedzielne, o których można rozmawiać w domu.

\section{ZASADA INTERPRETOWANIA SŁOWA BOŻEGO \\ ZGODNIE Z NAUKĄ KOŚCIOŁA}

W 2 Liście św. Piotra zamieszczona jest ważna rada: „To przede wszystkim miejcie na uwadze, że żadne proroctwo Pisma nie jest dla prywatnego wyjaśnienia. Nie z woli bowiem ludzkiej zostało kiedyś przyniesione proroctwo, ale kierowani Duchem Świętym mówili święci ludzie" (2 P 1, 20-21). Podstawową zasadą interpretacji Pisma Świętego jest więc jego czytanie z pomocą tego samego Ducha, z pomocą którego zostało napisane (Sobór Watykański II, konst. Dei verbum, 12). Przed błądzeniem po manowcach fałszu chroni autorytet Kościoła. Dlatego niezbędne jest odwoływanie się do niego, czemu sprzyja żywy kontakt rodzin z duszpasterzami.

\section{ZASADA WPROWADZANIA SŁOWA W CZYN}

Zasadniczym celem słuchania słowa Bożego jest wiara, która znajduje wyraz w praktyce chrześcijańskiego życia. Jezus Chrystus miał wielu słuchaczy, ale swoimi braćmi nazwał jedynie tych, którzy jak Maryja „słuchają słowa Bożego i wypełniają je" (Łk 8, 21). Również apostołowie zwracali uwagę na to, że właściwe słuchanie słowa Bożego prowadzi do uczynków miłości. Św. Jakub napominał chrześcijan: „Wprowadzajcie zaś słowo w czyn, a nie bądźcie tylko słuchaczami oszukującymi samych siebie” (Jk 1, 22), a św. Jan nakazywał kochać bliźnich nie „słowem i językiem, ale czynem i prawdą" (1 J 3, 18). Myśl tę rozwinął św. Maksym Wyznawca, stwierdzając, że „Słowa Boże, jeśli są jedynie wypowiadane, nie zostaną wysłuchane, ponieważ brak im głosu, którym jest praktykowanie tego, co one mówią. Jeśli natomiast wypowiada się je, a zarazem wypełnia przykazania, to

${ }^{13}$ Commentarius in Ecclesiasten, 313, [w:] S. Hieronymi presbyteri opera, pars 1: Opera exegetica, v. 1: Opera exegetica. Hebraicae Quaestiones in Libro Geneseos. Liber Interpretationis Hebraicorum Nominum. Commentarioli in Psalmos, cura et studio P. de Lagarde, G. Morin, M. Adriaen, Turnholti 1959, 278 (Corpus Christianorum. Series Latina, 72). 
dzięki temu głosowi mają moc wyganiać demony i skłaniać ludzi do budowania świątyni Boga w sercu poprzez rozwijanie dzieł sprawiedliwości"14.

Dla wielu pokoleń chrześcijan budującym przykładem uważnego słuchania słowa Bożego i wprowadzania go w życie był św. Antoni Pustelnik. W jego żywocie napisanym przez św. Atanazego czytamy, że pewnego dnia Antoni przybył do świątyni i usłyszał słowa Chrystusa skierowane do bogatego młodzieńca: „ «Jeśli chcesz być doskonałym, sprzedaj wszystko, co masz, i rozdaj ubogim, potem przyjdź i pójdź za Mną, a będziesz miał skarb w niebie». Antoniemu zdawało się, jak gdyby sam Bóg przemówił do niego słowami Ewangelii, jakby czytanie to przeznaczone było dla niego. Wyszedł natychmiast z kościoła i rozdał mieszkańcom wioski odziedziczoną po rodzicach ziemię, aby odtąd nie była dla niego i jego siostry ciężarem. Sprzedał także wszelkie inne dobra, a pieniądze rozdał ubogim. Tylko niewielką ich część zachował ze względu na siostrę"15.

O tym, jak należy skutecznie słuchać słowa Bożego, przekonująco mówił Søren Kierkegaard. Załóżmy - zauważył - że zwierciadło słowa Bożego ukazało komuś jakąś wadę, np. uzależnienie od hazardu (możemy w to miejsce wstawić naszą słabość). Jeśli człowiek ten powie sobie: obiecuję, że dzisiejszego wieczoru zagram po raz ostatni, a potem nie będę grał już nigdy więcej - taka postawa oznacza porażkę. Człowiek ten powinien był powiedzieć: we wszystkie kolejne dni będę mógł grać, tylko nie dziś wieczorem. Jeśli dotrzyma słowa, będzie ocalony i znajdzie siły do przezwyciężenia wady. Pierwsze postanowienie było tylko żartem zrobionym mu przez jego namiętność, drugie - jego drwiną z własnej namiętności ${ }^{16}$.

\section{Owoce wychowania do słuchania słowa Bożego}

Zgodnie z nauczaniem Chrystusa pedagogika chrześcijańska zwraca uwagę na owoce wychowania, czyli wyniki pracy wychowawczej. Są nimi m.in. umiejętność rozmawiania z Bogiem i dojrzała religijność. Przykładem skutecznego wychowania do słuchania słowa Bożego są święci, a także rzesza niekanonizowanych sług Bożych. Wśród nich jest Antonietta Meo, choć przeżyła na świecie niespełna siedem lat. Urodziła się 15 grudnia 1930 roku w Rzymie, w rodzinie o solidnych zasadach moralnych i religijnych, jak zostało zapisane w jej życiorysie przygotowanym w czasie pro-

${ }^{14}$ Capitum theologicorum et oeconomicorum duae centuriae IV, 39, [w:] S. P. N. Maximi Confessoris Opera Omnia, accurante et denuo recognoscente J.-P. Migne, t. 1, Lutetiae Parisiorum 1865, 1084 (Patrologiæ cursus completus. Series Graeca, 90).

${ }^{15}$ Św. Atanazy, Żywot św. Antoniego (rozdz. 3), [w:] Liturgia godzin, t. 3, Poznań 1987, S. 1050 .

${ }^{16}$ Cyt. za: R. Cantalamessa, Tajemnica głoszenia słowa Bożego, Wrocław 2007, s. 93-94. 
cesu beatyfikacyjnego. Gdy miała pięć lat, uderzyła kolanem o kamień, a gdy ból nie przechodził i rodzice udali się z dzieckiem do lekarza, usłyszeli diagnozę: nowotwór (osteosarcoma). Trzeba było amputować nóżkę. Antonietta przyjęła to doświadczenie nie jako tragedię, lecz sposobność do cierpienia za świat i grzeszników. W rocznicę amputacji 25 kwietnia 1937 roku Antonietta powiedziała rodzicom, że trzeba świętować to wydarzenie, a żartując wobec cioci, doprecyzowała: „Nie straciłam nóżki, ale ją podarowałam Jezusowi”. Ku radości Antonietty rodzice postanowili przyśpieszyć jej Pierwszą Komunię Świętą. Toteż wieczorami mama uczyła córkę katechizmu. Na zakończenie rozważań, począwszy od 15 września 1936 roku Antonietta najpierw dyktowała mamie, a potem sama pisała listy do Boga, do Pana Jezusa, do Ducha Świętego i do Matki Bożej. Mama składała te kartki przy figurce dzieciątka Jezus. Świadczą one o mistycznym wręcz zjednoczeniu Antonietty z Jezusem. Często powtarzała: „Panie Jezu, daj mi dusze”. Ostatnia kartka datowana jest na 2 czerwca 1937 roku. Antonietta podyktowała mamie słowa: „Kochany Ukrzyżowany Jezu, bardzo Cię kocham. Pragnę być z Tobą na Kalwarii”. Dziewczynkę ogarnęły torsje, a gdy minęły, kontynuowała: „Kochany Jezu, chcę Ci powtórzyć, że kocham Cię bardzo, bardzo”. Zmarła 3 lipca 1937 roku, co sama zapowiedziała na dziesięć dni przed śmiercią. Jej trumna spoczywa w bazylice Świętego Krzyża Jerozolimskiego, gdzie Antonietta 28 grudnia 1930 roku przyjęła chrzest, a kilka lat później - Pierwszą Komunię Świętą. O wszczęcie procesu jej beatyfikacji zatroszczyła się Akcja Katolicka, do której dziewczynka należała ${ }^{17}$.

Rodzi się pytanie o to, jak w tak młodym wieku można dojrzeć do świętości, i to jeszcze uznanej przez Kościół. Z pewnością jest to skutek szczególnego wybrania przez Boga i działania Jego łaski. Niebagatelną jednak rolę w duchowym dojrzewaniu Antonietty odegrała atmosfera domu rodzinnego, w którym prowadzono religijne rozmowy, rozważano słowo Boże, otaczano szacunkiem symbole religijne, a sam Bóg był traktowany z wielką powagą i miłością, jako ktoś bliski i bardzo dobry, z kim można rozmawiać.

${ }^{17}$ Por. Watykan: siedmioletnia Włoszka będzie najmłodsza błogosławiona, http://ekai.pl/ wydarzenia/x13739/watykan-siedmioletnia-wloszka-bedzie-najmlodsza-blogoslawiona (18 XII 2007); La vida de Antonietta Meo: “HHabrá santos entre los niños!”, http://www.aciprensa.com/vejemplares/nennolina.htm (8 II 2009); Sierva de Dios fallecida a los seis años "brilla para darnos luz a todos", destaca sacerdote, http://www.aciprensa.com/noticia.php?n=19541 (19 XII 2007); 6-Year-Old on Way to Sainthood. Pope Approves Decree of Heroic Virtue, http:// www.zenit.org/article-21327?1=english (18 XII 2007). 


\section{Zakończenie}

Obserwacja codziennego życia pozwala stwierdzić, że dla wielu rodziców lekcja religii w szkole stała się substytutem religijnego wychowania w rodzinie. Niezbędne jest więc budzenie u chrześcijańskich rodziców świadomości, iż są pierwszymi i trudnymi do zastąpienia wychowawcami również na drodze wiary. Wiara dzieci i młodzieży rozwija się najlepiej wtedy, gdy słowo Boże dociera do nich w warunkach codziennego, najbliższego otoczenia, jakie stwarza rodzina. Żeby jednak rodzice mogli wychować swoje dzieci do słuchania słowa Bożego, sami muszą być odpowiednio uformowani.

W ostatnich latach m.in. pod wpływem debat społecznych rozwinęły się w Kościele rozmaite duszpasterstwa specjalistyczne, np. małżonków, którzy nie mogą mieć dzieci, czy małżeństw żyjących w związkach niesakramentalnych. Nie można wszakże w duszpasterstwie zwyczajnym tracić z oczu małżeństw i rodzin pragnących prowadzić bardzo intensywne życie wiary oraz wprowadzać na tę drogę swoje dzieci. Innych rodziców natomiast należy uwrażliwiać na fakt, że samo chodzenie w niedzielę do kościoła to stanowczo za mało. W obliczu coraz większego pluralizmu kulturalnego i religijnego, jakiego doświadczamy po wstąpieniu do Unii Europejskiej, niezbędna staje się praca dorosłych chrześcijan nad pogłębianiem swej tożsamości religijnej. Szczególną pomocą służą ruchy odnowy.

Zadaniem zaś duszpasterzy jest unikanie banalizacji treści homilii, zwłaszcza kierowanych do dzieci. Homilie będą o wiele skuteczniejsze, gdy zostaną skierowane do rodziców z dziećmi, bo to właśnie rodzice wywierają najsilniejszy wpływ wychowawczy na dzieci.

Kraków

KS. HENRYK SEAWIŃSKI

\section{Słowa kluczowe}

Wychowanie religijne, dziecko, rodzina, słowo Boże

\section{Summary}

The preparation of the child in the family to listen to the word of God

The article deals with the issue of children being encouraged to listen to the word of God under parental guidance. The case of Samuel described in the Book of Samuel (1 Sm $3,4-5.8-10)$ shows that preparing children to listen to the word of God is possible and needed. God may talk to people directly in their consciousness, but this is by extraordinary means. God chooses the mediation of people as a regular way of communicating with the human beings. It is the parents who play the most important role in the process of preparing the child to listen to the word of God. In general, the aim of this is to strengthen their integral faith, i.e. the faith influencing daily life. There are also some particular aims discus- 
sed in the article, followed by some methods of helping pupils to develop their skill to give heed to the word of God, and the rules which should be respected in the discussed process. As the end of the article the case of Antonietta Meo is being presented as the fruit of good religious upbringing towards the listening to the words of God.

\section{Keywords}

Religious upbringing, child, family, the word of God 
